\title{
4
}

\section{Integrated Ports Clusters and Competitive Advantage in an Extended Resource Pool for the Antwerp Seaport}

\section{Elvira Haezendonck and Mychal Langenus}

\section{Introduction}

Ports currently face an environment characterized by increased scale of carriers and vessel sizes, stakeholder opposition to port expansion, and heavy regulation. Therefore, ports are preparing strategic responses. A possible response could entail the development of strategic partnerships, or any form of collaboration, which could allow them to obtain one or more competitive advantages through more or alternative combinations of unique resources. This assumes of course that the specific type of collaboration does not lead to such a (low) level of competition, conflicting with antitrust regulation (Suárez-Alemán et al. 2017).

Two types of collaboration exist: vertical and horizontal collaboration. The former refers to collaboration along the supply chain or in

This chapter originally appeared as an article published in Maritime Policy and Management 45, online 09 May 2018. It is available https://doi.org/10.1080/03088839.2018.1471535.

E. Haezendonck $(\bowtie) \cdot$ M. Langenus

Department of Business, Vrije Universiteit Brussel (VUB), Brussels, Belgium e-mail: elvira.haezendonck@vub.be 
the case of ports logistics chain, and which could also be termed "coordination." The latter refers, alternatively, to collaboration along a port range or between (competing) ports, also termed "cooperation" or "co-opetition" (Song 2003; Brooks et al. 2009). In this paper, we focus on port coordination and analyze its potential impact on creating more or new competitive advantages for the integrated port. Ports engage in coordination efforts, as they need to have a competitive advantage in contestable hinterlands (De Langen 2008). In fact, ports compete to a large extent by the efficiency and effectiveness of their hinterland networks (Robinson 2002; Notteboom and Rodrigue 2005). We divided the geographical scope of a port's coordinated or integrated network into respectively, from near to remote, three extents: proximate inland terminals, dry ports, and inland navigation terminals or hubs. A landlord port authority, although it has limited influence, can introduce various coordination mechanisms to influence the conditions under which hinterland transport networks work (Van der Horst and De Langen 2008; De Langen 2008). As put forward by Brooks et al. (2009: 40) research on port collaboration should look on "what makes for successful cooperative activities." In addition, it is also interesting to look at cases where no substantial positive result occurs from collaborative efforts. In fact, ports may well enter into specific forms of collaboration without contemplating if such efforts will indeed result in positive outcomes.

We take an extended resource-based view perspective (McEvily and Zaheer 1999; Lavie 2006) to study the competitive advantages of an integrated port cluster. We apply the framework on the case of the port of Antwerp. The contributions of the study are twofold: first, the present study aims to determine empirically, based on an extended version of Porter's (1990) "diamond" framework, and on new data, the determinants of the competitive advantage of the Antwerp port cluster as compared to its rivals. Second, we compare the sources of competitive advantage found in the original value chain of ports based on the competitiveness matrix of Haezendonck et al. (2000) with the more relevant matrix today, given the integration of the port into its hinterland, and which is applied in this paper. Based on the vertical collaboration focus, we will analyze what could, or should drive port collaboration, and how an extension of a port's vertical boundaries actually impacts its competitiveness. 
The structure of the study is as follows: in Sect. 2 we discuss the literature regarding competitive advantages of ports and the extension toward the hinterland. After that, Sect. 3 focuses on the adopted methodology. Results are provided in Sect. 4 and discussed in Sect. 5, before offering conclusions and policy recommendations in Sect. 6. Section 7 finally entails the limitations and recommendations for future research of the study.

\section{$2 \quad$ Literature Review}

\subsection{Competitive Advantages of Ports}

The resource-based view (RBV) theory defines that competitive advantages can be created if a firm is successful in the creation of a strategy that is based on resources that are difficult to be duplicated by a competitor (Barney 1991; Wernerfelt 1984). Such resources can be "assets, capabilities, organizational processes, firm attributes, information, knowledge, etc. controlled by a firm" (Barney 1991: 101). In order to be a potential source of competitive advantage, an underlying resource bundle must be rare, valuable, inimitable, and non-substitutable. Only if a unique bundle of resources is formed, perceived as valuable by customers and consciously deployed in a focal firm's strategy, can it be regarded as a competitive advantage. However, we must also note that once a competitive advantage has been attained, its sustainability in the longer run is not guaranteed (Barney 1991: 103).

Although various valid and complementary models exist to analyze competition and competitiveness of ports, such as a game-theoretical approach (applied by e.g., Anderson et al. 2008), ports co-optition (e.g., Heaver et al. 2001; Song 2003), multicriteria analysis (e.g., Teng et al. 2004), and review studies leading to modeling frameworks for port competition have been conducted (e.g., Wan et al. 2018), the resourcebased view has, for almost two decades now, proven its relevance and impact in (trans)port studies. Haezendonck et al. (2000) were the first to empirically analyze the competitive advantages of a seaport through the development and analysis of a matrix, by which they identified 
the port of Antwerp's competitiveness determinants. The matrix had on the horizontal axis the functional activities of the port from a logistics chain perspective (Cooper 1994), and on the vertical axis the resources as derived from the extended "diamond" framework of Porter. The extended "diamond" framework incorporates "government" as a fifth key element next to the four original elements of the diamond framework, which are: factor conditions, demand conditions, related and supporting industries and firm strategy, structure and rivalry (Porter 1990).

Later, Gordon et al. (2005) have applied the resource-based view to study the competitive advantage of the Port of Singapore (PSA) and Acosta et al. (2007) have analyzed the competitiveness of the Algeciras port using the extended diamond of Porter. Besides the interesting port-related findings, Gordon et al. (2005) propose that managers should, in their pursuit of attaining a superior yet sustainable competitive edge, not only consider the resources internal to the organization but also identify external resources, and furthermore develop internal resources that can build on those external resources, which relate to the earlier idea of "dynamic capabilities" developed by Teece et al. (1997). Through a continuous interaction of both types of resources, a competitive advantage could be sustained for a firm. Acosta et al. (2007) included all the institutions and companies involved in the containerization process, but those were not explicitly integrated in the port cluster from the port authority's perspective.

Interestingly in this context, McEvily and Zaheer (1999) put forward that the resource-based view can be extended to the network level or a cluster of organizations. A cluster can be defined as "geographic concentrations of interconnected companies, specialized suppliers, service providers, firms in related industries, and associated institutions (e.g. universities, standards agencies, trade associations) in a particular field that compete but also cooperate" (Porter 2000: 15). Network resources are then those resources, which are external to the focal firm but are embedded in the network, and offer strategic opportunities to influence the value of the focal firm (Lavie 2006). In line with Lavie (2006), Wassmer and Dussauge (2011), and Jans (2016), in combination with the previously stated findings of Teece et al. (1997), and Gordon et al. (2005), we follow the idea that the cluster environment offers the focal 
organisation an environment where network resources can be combined with the non-shared resources of the firm in a unique way, offering potential for new competitive advantages. In this way, performance heterogeneity can still exist, and in optimal cases a cluster firm would have superior performance relative to a non-cluster firm (Jans 2016).

\subsection{Port Collaborative Network as Extended Resource Base}

In general, inter-organizational alliances have risen in popularity since the 80s (Gulati 1998; Gulati et al. 2000; Hagedoorn 1993, 1995; Lavie 2006). Collaborative agreements can take many forms with the inter-organizational dependence, varying from negligible, e.g., in start-up assistance agreements or technical training, to high, e.g., co-production of goods or services or technology or equity joint ventures (Contractor and Lorange 1988; Song 2003). Two more general types of collaboration occur in the ports industry: vertical and horizontal collaboration. The former type refers to collaboration along the supply chain. This type of collaboration is also referred to as "coordination." The latter type refers, alternatively, to collaboration along a port range or between ports, also termed "cooperation" or "co-opetition" (Song 2003; Brooks et al. 2009). The World Bank, which commissioned a study in 2007 (The World Bank 2007) concerning inter-port cooperation, believes that neighboring ports can boost their competitiveness by working together and by innovating, and thus create additional salient sources of competitive advantage. Furthermore, Chiang and Hwang (2009) advocate that ports in the same region should cooperate and integrate to enhance competitiveness. Despite such reasoning, ports located in the same range usually compete fiercely for cargo and to maintain complete or partial control over customers, market share, and hinterlands (Marlow and Paixao 2001; Cahoon et al. 2013). The tendency of port authorities, located in the same geographical region, to compete rather than cooperate, has been earlier described by Wang and Slack (2004) and in the context of container port efficiency by Yap and Lam (2004). Shipping lines and operators, whose combined presence and market 
share in multiple ports gives them more power, have gained this power through consolidation and alliances. Their resulting, growing scale and importance to the port, may limit, in turn, the power and influence of the different port authorities downstream the port's value chain. Ports may respond to increase their power through for example mergers, more influence on its logistics chain, or any form of collaboration which results in a growing port influence, as suggested by Carbone and De Martino (2003) and Song and Panayides (2008). However, little is known today on the empirical outcome of port integration, expansion, or collaborative partnerships, in terms of increased competitiveness or measurable efficiency gains. Very recently, Cui (2017) found that port scale expansion does not necessarily lead to environmental gains, and Xing et al. (2018) revealed that port integration may well lead to a reduction of social welfare and consumer surplus. Those are at least two empirical studies which demonstrate that as regards port collaboration, not all that glitters is gold.

In this paper, we focus on vertical collaboration or port coordination whereby a port authority formally engages into activities which were previously under full responsibility or ownership of organizations other than the port authority. Ports compete to a large extent by the efficiency and effectiveness of their hinterland networks (Robinson 2002; Notteboom and Rodrigue 2005). Hence, ports engage in coordination efforts, as they need to have a competitive advantage incontestable hinterlands (De Langen 2008). The geographical scope of a port's integrated network can be divided into respectively, from near to remote, three extents: proximate inland terminals, dry ports, and inland navigation terminals, or hubs. We have chosen this distinction in order for our results to be related to either remote or more distant collaborative efforts, of which some distinct cases do exist today for some European hubs, for example HAROPA, Antwerp port's collaborative agreement with the port of Liège, Rotterdam's willingness to take a large stake in Duisburg port, Thus, although a port authority has a limited domain of influence-under the most common form of a landlord port authority - a port authority can introduce different types of coordination mechanisms to impact the conditions under which hinterland transport networks work (Van der Horst and De Langen 2008; 
De Langen 2008; Rodrigue and Notteboom 2009). However (trans) port and maritime literature has not offered many insights in the vertical type of collaboration, and more specifically into which advantages or disadvantages this may or may not bring for a focal organization such as a port authority or cluster manager (e.g., De Martino et al. 2013; Hoshino 2010).

\subsection{Hinterland Extension: The Port Network}

Many authors have expressed the salience of the port network as a research unit to analyze regional container hub rivalry (Hayut 1981; Slack 1985; van der Horst and van der Lugt 2011). Ports in the same range compete for traffic volumes from and to shippers in their hinterland. Rodrigue (2010) identified hinterland connections as a key factor in port competitiveness. Good connections to the hinterland have become more relevant in the competition among container seaports, as ports are no longer considered as single actors, but as key parts of the logistics chain. With the optimization of logistics and inland transport networks, more shippers in an extending hinterland could potentially be reached via seaports. How well a seaport succeeds in efficiently reaching this extended hinterland, through, for example, participations in inland terminals, may as such co-determine its competitiveness. It may enable inland corridor formation, allowing load centers to access formerly captive hinterlands of other ports. With increasingly captive hinterlands, inter-port competition has increased as well. This inter-port competition, in combination with the complexity of hinterland logistics, requires ports to be more proactive in their hinterland strategies. Hinterland connections have thus become an essential part of the ports' distinct value propositions (Bergqvist 2012). Especially, since inland transport nodes are becoming more and more essential due to the saturation of terminal storage capacity and the shipping liners adoption of hub-and-spoke distribution strategies (Ducruet and Notteboom 2012).

Rodrigue et al. (2009) underline the growing inter-port hinterland competition and state that the development of land transport has allowed ports and their container terminals to extend their hinterlands 
to reach captive markets from other ports of their region. Hence, ports can be seen as elements in a value-driven chain, whereby the port captures value for itself and for the chain it is a part of (Robinson 2002). This is already argued by Notteboom and Winkelmans (2001), who state that seaports and shipping lines vertically integrate to further control hinterland transport. Wilmsmeier et al. (2011) add to this that port authorities have a role in this, and need to be active in extending or maintaining their hinterland. The more dominant role of the ports in the hinterland is also in evidence offered by Haralambides and Gujar (2011), who argue that the overall supply chain can benefit from an extension of the sea-terminal connection into the hinterland. This extension has multiple positive effects, e.g., overall benefits in terms of the logistics chain's performance, modal shift opportunities, and regional development effects.

Given the expected positive influence of an integrated hinterland for seaports to compete, we decided to analyze this for three distance related levels of integration: proximate inland terminals, dry ports, and inland navigation terminals, or hubs. The first level is based on the extended gate concept. Veenstra et al. (2012) consider new responsibilities in addition to being a "stocking point"; they propose supply chain and transportation network integration by extending the sea-terminal gate into the hinterland, the extended gate. They argue that extended gates, when implemented correctly, can generate substantial benefits in terms of modal shift, logistics performance, and regional development, and therefore contribute to the competitiveness of seaports. The second level can be supported by Notteboom and Winkelmans (2004) and Cullinane et al. (2012), who state that also dry ports play an important role in the competitiveness of seaports. According to these authors, to remain valid, container terminals are obliged to constantly reassess their customers, to reconfigure competitive concepts like the hinterland, foreland, and captive markets, and to extend their role in the supply chain through the inland integration of port services. Cheung et al. (2003) dig deeper into the possible advantages of advancing further into the hinterland through inland hubs: this might often be attractive for shippers to outsource value-adding services such as packaging and sequencing to logistics service providers at strategically placed nodes. 
The third level finds support in Van den Berg and De Langen (2011) and Verhoeven (2009), who claim that inland terminals play a crucial role in the competitive position of the port in the hinterland, as ports have become dependent on intermodal transport networks to maintain or extend their competitive position.

In sum, the competitiveness of a port today seems to heavily depend upon the network in which it operates. Instead of restricted to the functions within the seaport area itself, an extension of the logistics chain is part of the new business model of port authorities. Hence, the basic assumption for this paper is that the extended resource base of today's integrated ports would lead to more opportunities for creating competitive advantages for ports.

We build on the competitiveness-matrix developed by Haezendonck et al. (2000), where functional activities performed within the port from a logistics chain perspective (Cooper 1994) were combined in a matrix with the resources required to perform those activities, as suggested by the extended diamond framework of competitive advantage (Porter 1990). In fact, we have added the port network within the logistics chain perspective, being the elements on the horizontal axis of the matrix. This network dimension is added on the right in the matrix, see Fig. 1, with the green colored columns, adding potential determinants to the original competitiveness matrix (Haezendonck et al. 2000), which leads to a new, extended competitiveness matrix as shown in Fig. 1.

In Fig. 1, the columns under port network stretch the port value chain further into the hinterland, and consists based on the above of the three sub-columns: proximate inland terminals, dry ports, and inland navigation terminals/hubs. These columns detail port value creating activities gradually located more inland than the original activities considered based on port logistic chain activities as considered by Haezendonck et al. (2000) in their competitiveness matrix using Button's (1993) value activities for ports. The proximate inland terminal refers to the area just outside the port area, and the dry port refers to inland located intermodal terminals, which connect the port with the hinterland and might be a potential base of extended activity of the port itself, defined by UNCTAD (1982), i.e., as a place inland that fulfills 
要

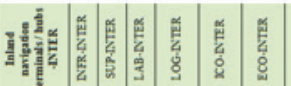

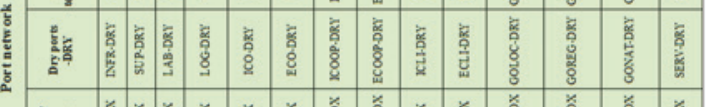

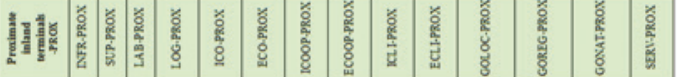

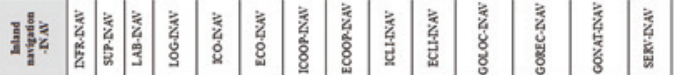

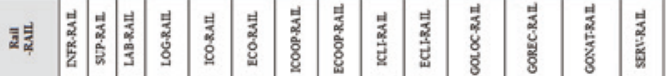

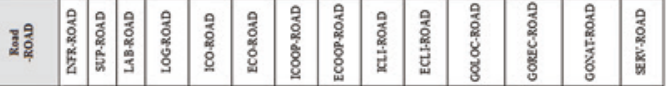

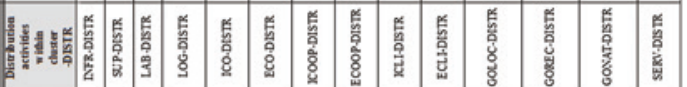

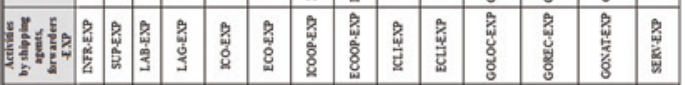

\begin{tabular}{|c|c|c|c|c|c|c|c|c|c|c|c|c|c|c|}
\hline 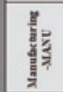 & 章 & & $\begin{array}{l}2 \\
\frac{3}{3} \\
8\end{array}$ & 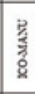 & 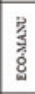 & 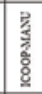 & 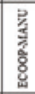 & \begin{tabular}{|l} 
意 \\
竞 \\
\end{tabular} & 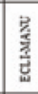 & $\begin{array}{l}2 \\
8 \\
8 \\
8\end{array}$ & 8 & & 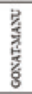 & 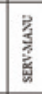 \\
\hline
\end{tabular}

竞

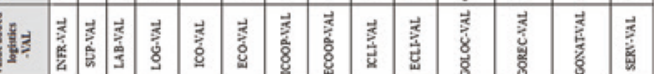

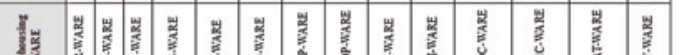

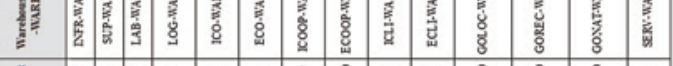

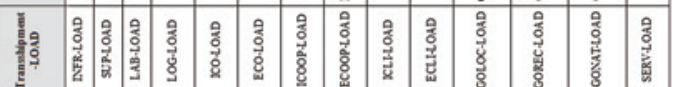

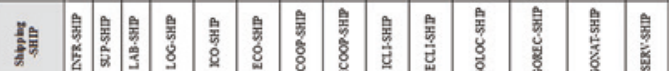

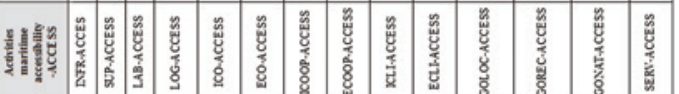

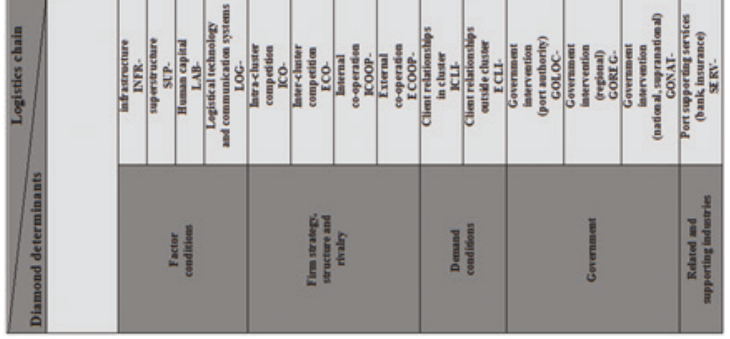


original port functions. The inland navigation terminals/hubs refer to the existence of a port cluster from inland terminals and inland ports with whom the port is in a structural relationship, for example, by taking shares in these terminals or being a member of their board. The advantages of the implementation of the dry port concept may come from decreasing port congestion, alleviating pressure on storage space, reducing handling operations and time spent in ports, and lowering transaction costs to shippers. This dry port function has been described by Roso et al. (2009): inland intermodal terminals, directly connected to a seaport by rail, which enables activities to be transferred from the seaport to a more inland located trimodal logistic location to relieve congestion and achieve other benefits (e.g., potential of modal split, multimodal platform).

\section{Empirical Analysis of Competitiveness Determinants of the Integrated Antwerp Seaport Cluster}

In this section, we explain how we collected and analyzed our data for the extended competitiveness matrix. We introduce the sample, survey method, and elaborate on data analysis before we present the results in Sect. 4.

\subsection{Sample and Method}

By means of a questionnaire, including the extended competitiveness matrix, used as a basis for interviewing 59 C-level managers from June 2013 until December 2013, the competitive advantages and disadvantages of the port cluster of Antwerp, vis-à-vis the main competitors for containers and conventional cargo in the Hamburg-Le Havre range ports, were determined. We identified all potential expert-participants 
by researching which organizations were involved in the core business of the extended port cluster and in the container traffic segment in particular. The selected experts were mostly responsible for the strategic/planning department of the ports main actors $(\mathrm{N}, \mathrm{N}-1$, and $\mathrm{N}-2$ management levels), i.e., terminal operators, shipping companies, agents, forwarders, experts and also some key industrial actors in the port area, mainly petrochemical companies in the Antwerp seaport.

\subsection{Survey Method}

The first part of the questionnaire contained general questions, related to the size and scope of the company active in the Antwerp port and its traffic specialization. The second and main part of the interview was based on the port's "extended competitiveness-matrix" (see Fig. 1). The third part of the questionnaire contained open-ended questions, which allowed for better understanding and interpreting of the different scores of the competitiveness matrix. The survey was complemented with a separate, detailed list of all matrix variables and their definition, in order to make clear what is meant by each variable. In practice, the respondents had this sheet next to the competitiveness matrix when providing their answers. All interviews took place at the office of the expert-participants. Two experiences researchers, of which one has been responsible for several similar surveys in the past 2 decades, personally carried out all interviews and noted down themselves the answers provided by the respondents. This allowed for a structured process, with structured criteria.

Each variable (cell) in the extended competitiveness matrix represents the combination of an individual activity (in columns, 14 in total) with a selected resource (in rows, 14 in total), with its name based on the abbreviation of the respective resource and activity in the port cluster (Fig. 1). For example, the variable that combines the infrastructure (INFR-) that is necessary for maritime accessibility (-ACCES) is named "INFRACCES." In line with the more limited analysis of port competitiveness determinants in 1998 (Haezendonck et al. 2000), all respondents were asked to provide a discrete score $(-2$ to +2 on 
a five-point Likert-scale) for all variables in the matrix in terms of each variable's perceived negative or positive impact on the competitiveness of the port of Antwerp compared to its main rivals in the HamburgLe Havre range. The neutral score 0 was given for those variables considered neither an advantage, nor a disadvantage for the port cluster. Each variable can be viewed as a single source of co-determinant of a seaport cluster's competitiveness, on which competitive advantages or disadvantages may be built.

\subsection{Descriptive Statistics and Data Analysis}

For each respondent included in the survey, we obtained a completed extended competitiveness matrix, with scores for 196 variables. The following steps were taken to raise the validity of the interviews: first, interviews were conducted by the same team of two researchers; second, each identified stakeholder group (shipping liners, operators, agencies, and experts) had more than 15 respondents, and industrial actors were sufficiently represented as well. For example, experts from all major shipping companies within the container alliances operating at the data collection period, see Table 1, and operating in the port of Antwerp, were surveyed.

Table 1 Major alliances and their members in 2015

\begin{tabular}{llllllll}
\hline $2 \mathrm{M}$ & $28.3 \%$ & CKYHE & $17.1 \%$ & G6 & $18.4 \%$ & $\begin{array}{l}\text { Ocean } \\
\text { Three }\end{array}$ & $14.6 \%$ \\
\hline Maersk & $15.1 \%$ & COSCO & $4.3 \%$ & APL & $2.9 \%$ & CMA CGM & $8.9 \%$ \\
MSC & $13.2 \%$ & "K" Line & $2.0 \%$ & Hapag-Lloyd & $5.0 \%$ & CSCL & $3.6 \%$ \\
& & Yang Ming & $2.4 \%$ & HMM & $1.9 \%$ & UASC & $2.1 \%$ \\
& & Hanjin & $3.3 \%$ & MOL & $3.2 \%$ & & \\
& & Evergreen & $5.1 \%$ & NYK Line & $2.5 \%$ & & \\
\hline
\end{tabular}

The percentages represent the share of the shipping line as a percentage of the world fleet

Source Based on Alphaliner top 100. Retrieved from http://www.alphaliner.com/ top 100/, last consulted on July 6th 2015 
However, prior to further analysis, bias correction was necessary for multiple reasons: first, to avoid possible bias caused by the potentiality of the results of the study being used for political lobbying (Haezendonck et al. 2011); second, as with the earlier study (Haezendonck et al. 2000) a number of respondents systematically gave more extreme answers, whereas others were more moderate; this was probably due to variations in personality or attitudes of the respondents rather than a reflection of factual differences in the parameters underlying the competitiveness of the port of Antwerp. To adjust for this, $z$-scores were computed per respondent by centering on the average and scaling by the standard deviation of the whole respondent sample.

Based on the survey data collected in this average competitiveness $z$-matrix, linear regression analysis was performed using IBM SPSS statistics version 22.0, to reveal which activities (variables in columns) and resources (variables in rows) receive a positive or negative value. The regression model attempts to explain the scores in the average $z$-matrix by means of two categorical variables, namely the row and column indices. We encoded these categorical variables by binary dummy variables. The regression model was tested for multicollinearity (expressed as the variance inflation factor-VIF) and the standardized residuals, computed by this regression model for each cell of the matrix, were normally distributed. These residuals represent the difference between the real value of the $z$-score of each variable in the matrix and the estimated/fitted value of the $z$-score as predicted by the linear regression model. If the residuals are roughly normally distributed, around 95\% of them should lie between the cut-off values of -2.5 and 2.5. Cells of the matrix that corresponded with a standard residual value higher than 2.5 or lower than -2.5 were considered as basic sources of competitive advantages or disadvantages, respectively.

Additionally, we also applied factor analysis to understand how the individual high or low-scoring variables (the activities and resources of the extended competitiveness matrix) interact with each other. Hence, a potential relation between activities, see Table 2, or resources, see Table 3, could be detected, and we are able to screen for underlying dimensions in our data set or in other words for the existence of 
Table 2 Factor analysis on perceived value of the activities (2013)

\begin{tabular}{lll}
\hline & Factor & 2 \\
\cline { 2 - 3 } & 1 & .180 \\
\hline ACCESS & .706 & .135 \\
SHIP & .607 & .250 \\
LOAD & .784 & .166 \\
WARE & .695 & .251 \\
VAL & .709 & .380 \\
MANU & .481 & .290 \\
EXP & .821 & .416 \\
DISTR & .639 & .617 \\
ROAD & .361 & .552 \\
RAIL & .283 & .701 \\
INAV & .267 & .779 \\
PROX & .266 & .950 \\
DRY & .126 & .882 \\
INTER & .191 & \\
\hline
\end{tabular}

Source Results of the factor analysis (maximum likelihood), with Varimax rotation and Kaiser normalization of the value of the activities. The extracted factors account for a cumulative explained variance of $64.6 \%$

Table 3 Factor analysis on the perceived value of the resources (2013)

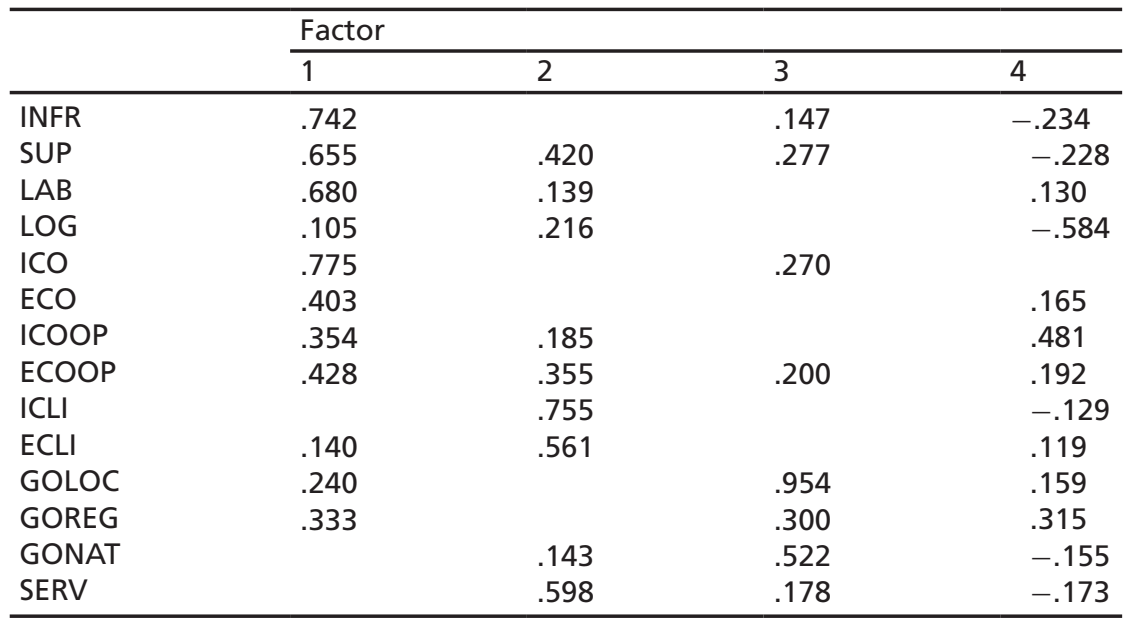

Source Results of the factor analysis (maximum likelihood), with Varimax rotation and Kaiser normalization of value of the resources. The extracted factors account for a cumulative explained 
a bundling phase of resources. These underlying dimensions are called factors.

To perform factor analysis on our dataset, the average score for the activity/resource for each respondent was calculated. For example, the average score for INFR in combination with all activities was calculated for each respondent. Consequently, this average score for INFR from each respondent was standardized by centering on the average and scaling by the standard deviation of the average score for INFR for all 59 respondents. This standardization made it easy to check for the correlations between all the different activities/resources. On this dataset, factor analysis (maximum likelihood) with Varimax rotation and Kaiser normalization as the rotation method was applied.

\section{$4 \quad$ Results}

\subsection{Results from the Extended Competitive Data Analysis}

When including the added port network elements in columns (in short: DRY, PROX, INTER) as determinants in the second regression analysis (explained variance of $61.8 \%$, with a VIF value of 1.857 ) in order to explore the new competitive position of the port of Antwerp, we observe a rather neutral impact for these three resources, as shown in Fig. 2 (in full black lines) and Fig. 3 (in full black dots). In other words, no significant positive or negative perceived value resulted from these added elements.

Based on the extended competitiveness-matrix results, linear regression analysis was applied as described above. From this analysis, we obtained the main effect of each activity (row) and resource (column) of the matrix. In Fig. 2, these are plotted with the main effects of the resources on the horizontal axis and the main effects of the activities on the vertical axis. The relative position of these values is a measure of the overall perceived value of both activities (columns) and resources (rows). We can clearly observe two outliers on the horizontal axis, RAIL (negative) and WARE (positive), in relation to the other variables. 


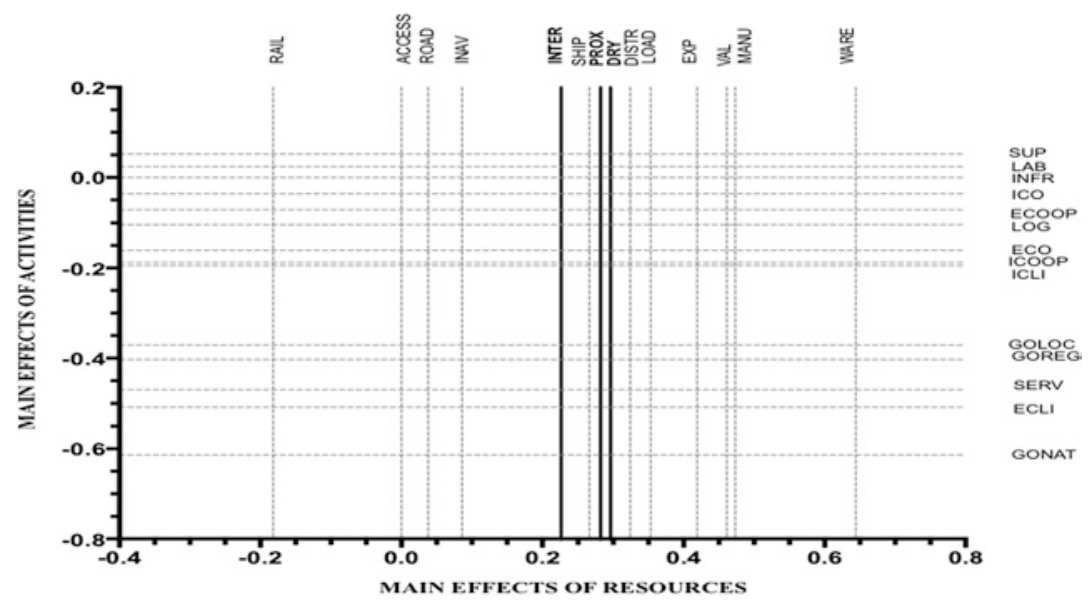

Fig. 2 Plot of the main effects of the activities and the resources (The dotted lines in grey represent the variables of the classic competitiveness matrix; the full lines in black represent the variables of the added port network components (i.e., PROX, INTER, DRY). Source Based on the results of regression analysis on the extended competitiveness matrix in SPSS)

From the main effects of the resources, we can observe an overall somewhat negative result.

To visualize the detected interactions, we plotted the standardized residuals (Fig. 3). These residuals represent the difference between the real value of the $z$-score of each variable in the matrix and the estimated/fitted value of the $z$-score as predicted by the linear regression model. If the residuals are roughly normally distributed, around $95 \%$ of them should lie between the cut-off values of -2.5 and 2.5 , which are presented as horizontal lines. Values lying far above or below these boundaries are outliers, referring to positive or negative interactions. In this figure, INFRWARE and SUPWARE are both identified as positive outliers, whereas INFRACCES appears to be a negative outlier.

Figure 4 is a combination of Figs. 2 and 3, i.e., the plot of the main effects of the activities (rows) and resources (columns) and the plot of the standardized residuals versus the fitted $z$-scores. In this threedimensional plot, the standardized residuals are plotted for each activity and corresponding resource, sorted by main effect, respectively. 


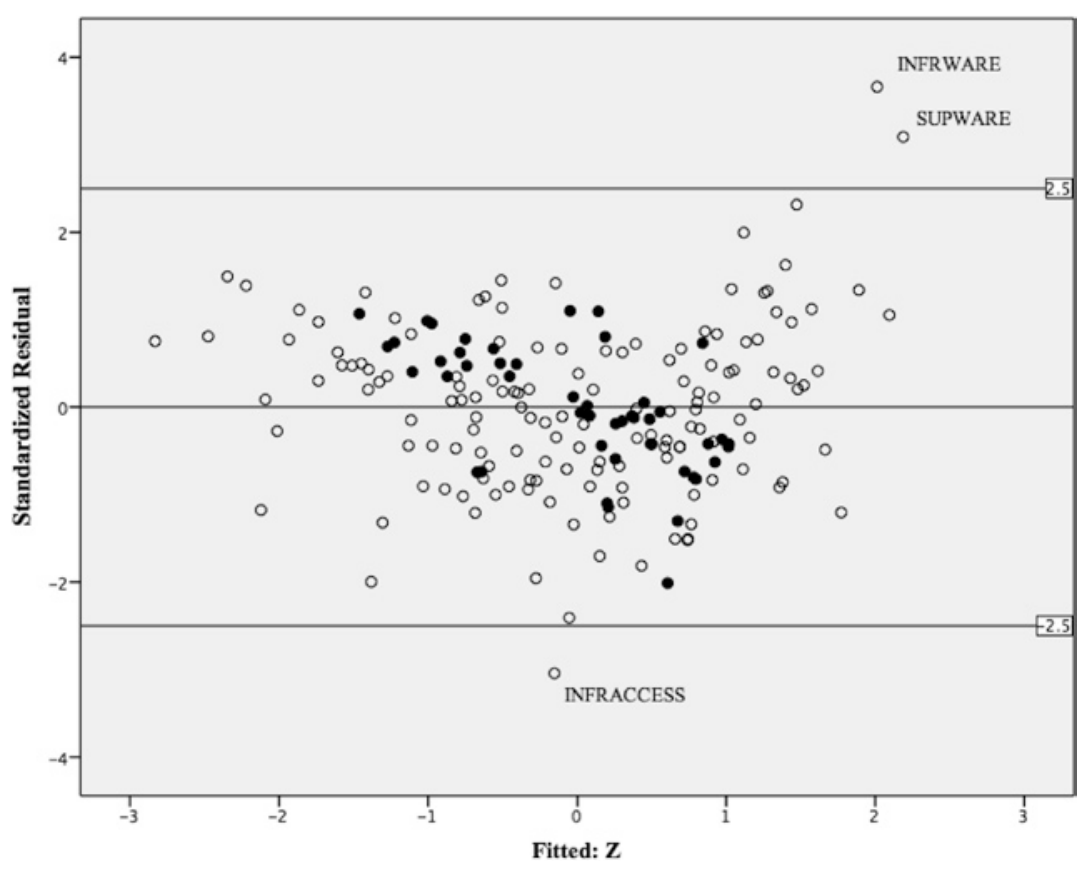

Fig. 3 Plot of the standardized residuals versus the fitted $z$-scores (The labeled points are the cells with the largest interaction. The white dots represent the variables of the classic competitiveness matrix, the black dots represent the variables of the added port network elements (i.e., PROX, INTER, DRY). Source Based on the results of regression analysis on the extended competitiveness matrix in SPSS)

The peaks and valleys in this plot correspond with the respectively positive and negative outliers found in Fig. 3.

Based on Figs. 3 and 4, we can observe important positive interactions between "infrastructure" and "warehousing" on the one hand, and "superstructure" and "warehousing" on the other (INFRWARE and SUPWARE).

Negative interactions (INFRACCES) can be observed between "infrastructure" and "maritime access." Concerning the results of the factor analyses on the perceptions of respondents, to define a set of crucial factors underlying the competitiveness of the Antwerp port cluster, two underlying factors were identified for the activities (see Table 2), whereas four factors could be extracted for the resources (see Table 3). 


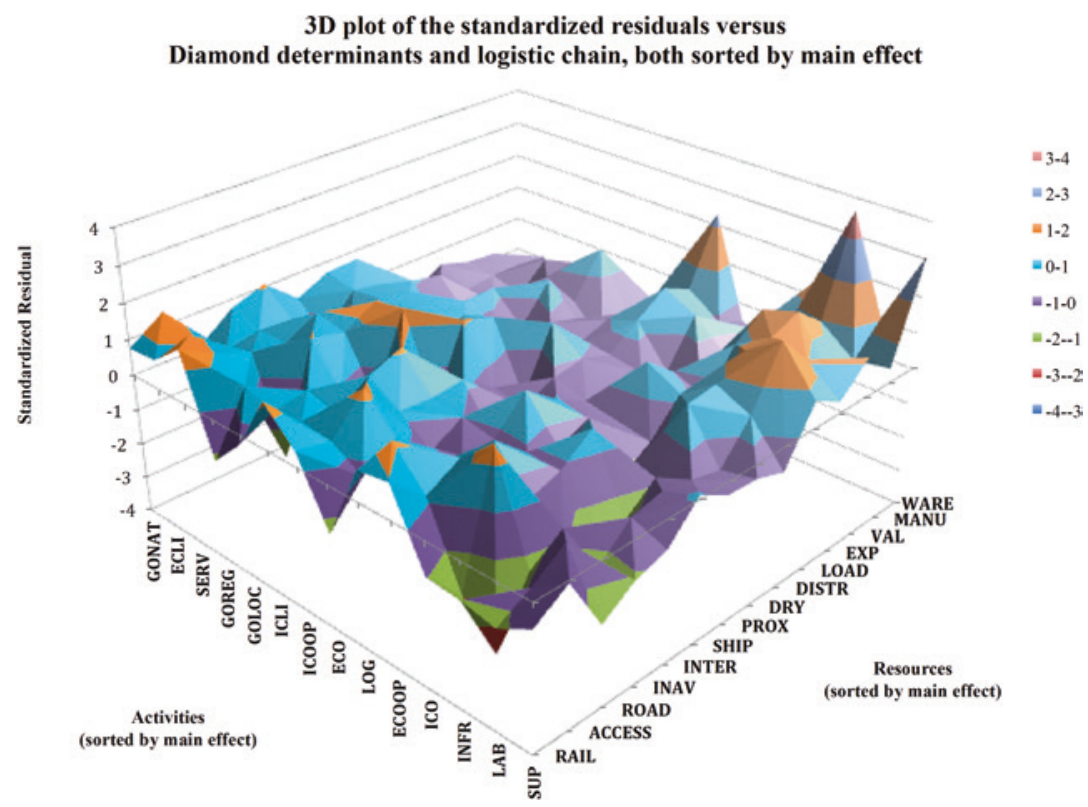

Fig. 4 Three-dimensional plot of the standardized residuals versus activity and resource, both sorted by main effect (Source Based on the results of regression analysis on the extended competitiveness matrix in SPSS)

For the activities, as represented in Table 2, factor one is determined primarily by activities in the port area (transshipment, warehousing activities, value added services, local industries, shipping agents and forwarding companies, and distribution activities in port) and factor two for the transporting activity to and from a port's hinterland. The first factor identified could therefore be viewed as "activities within the local port area itself." This means that the treatment of the ship, the moment it enters the port of Antwerp until it leaves the port of Antwerp, is still considered the Antwerp port's principal source of advantage vis-à-vis its rivals. The second factor is determined by the hinterland transport (inland navigation and road).

The factor analysis of the attributes of the port of Antwerp reveals four important factors, and the results hereof are shown in Table 3. The first factor is based on the factor conditions and firm strategy, 
structure and rivalry, whereas the second factor demonstrates a source of competitive advantage from the client relationships inside and outside the cluster. The third factor is based on the government, which refers to the intervention of local and federal governments and the European Commission in port policy, and whether these governmental actors boost the competitiveness of the port by facilitating trade, or, on the negative side, impose constraints on the competitive power of the port. The fourth factor (log) demonstrates the importance of activities that support logistics and how such activities are managed in the port. For example, communication systems are important in a seaport environment in order to better coordinate movements of containers and vessels and communications inside and outside of the port.

\section{Discussion of Results}

The use of the extended competitiveness matrix can be seen as an effective benchmarking tool for today's capturing of strengths and weaknesses underlying a port cluster's competitiveness, in this case of the port of Antwerp in comparison with its main competitors. Based on Figs. 3 and 4, variables INFRWARE and SUPWARE scored significantly positive, indicating the quality, capacity, and the diversified portfolio of these warehouses, being very salient for attracting and retaining shipping lines.

A negative interaction for INFRACCES was observed, which is between "infrastructure" and "maritime access," mainly due to the remaining time loss for ships entering the port benchmarked with Antwerp's rivals. The deepening of the Scheldt is moreover a continuous and expensive process.

The respondents also explained that the productivity and flexibility of the labor pool was the main underlying reason for Antwerp's competitive edge.

In fact, and when comparing with the original results of Haezendonck et al. (2000), only the availability of warehouses is revealed as a new, unique strength which may underlie a competitive advantage of the port. 
Most strikingly, we found no particular significant sources of competitive advantage of the port related to its recent integration efforts into the hinterland. We have found that the port cluster of Antwerp has indeed not acquired a significant competitive edge in the battle for the hinterland, at least not if integration was part of this strategy.

\section{Conclusions and Policy Implications}

In the recent context of increased power of shipping alliances, and reduced government support if no efficient scale is seemingly reached, ports strategically respond by integrating actively into their logistics chain. Various experts as well as papers in the academic literature suggest that this should allow ports to extend their valuable resources pool so that more sources of competitive advantages can be available to ports.

In this paper, we build on the extended resource-based view perspective (McEvily and Zaheer 1999; Lavie 2006), and we analyze the competitive advantages of the Antwerp port cluster, integrated into parts of its hinterland network area. In fact, the port undertakes collaborative actions in its direct to more distant hinterland by taking shares in terminals, building relationships through positions in boards of dry ports, etc., and aims to control, or at least tap into resources from these extended organizational borders after one or another form of integration. As observed before, such combination of internal and external, and/or nonshared and shared, resources can result in the creation of new, sustainable competitive advantages. Furthermore, ports are nowadays less competing as individual firms but more so as nodes in supply chains, which again compete with other supply chains. We therefore investigate if the extension in the port's network leads to additional sources of competitive advantages, vis-à-vis the competitive advantages obtained from within the originally more limited port area or strategically controlled by the authority. We would expect so, given that literature suggests that seaports should extend their view on resources beyond their own boundaries.

Our empirical analysis, based on an extended competitiveness matrix, and deploying a robust methodology as applied by Haezendonck et al. (2000), did however not prove that this port's integration strategy into 
its hinterland has been successful up until now and given the current scope of integration of the Antwerp seaport into its hinterland. It needs to be stressed that this research is exploratory in nature and somehow premature or at least in an early stage of integration and research development. We need more research efforts and cases for a discussion of precisely how the proposed findings and mechanisms might operate. Various relationships with a port's hinterland may need (more) time to develop and may also be very case dependent. That said, the results as shown in this paper point out that port integration into its hinterland, as a form of port collaboration, or a scale or scope extending strategy, does not automatically, nor immediately, lead to an increased competitiveness potential.

\section{Limitations and Future Research}

The results found in this analysis could be due to the case itself or to the specific level or nature of integration that the seaport has undertaken until the year of our data analysis. Other cases of integration of seaports that function as hubs around the globe, potentially with other governance structures, or activity scope, or other time frames-given that integration is a dynamic process which can vary over time-may provide additional interesting insights.

Further research could also focus on the (opportunistic) behavior of port authorities in exploiting future competitive advantages or developing dynamic capabilities. Additionally, it would be interesting to investigate how a particular port network evolves in the future, and if and how its competitiveness follows those dynamics.

Acknowledgements The authors would like to thank Prof. Dr. Alain Verbeke (Vrije Universiteit Brussel) for the provision of the financial support that allowed the data collection of this research, through the GOA project. For the statistical analyses included, the authors would like to thank Toon Valaert for his valuable contribution.

Funding: This work was supported by VUB, grant number GOA-75. 


\section{Annex 1: Interview Template: Determinants of Port Competitiveness}

1. General identification

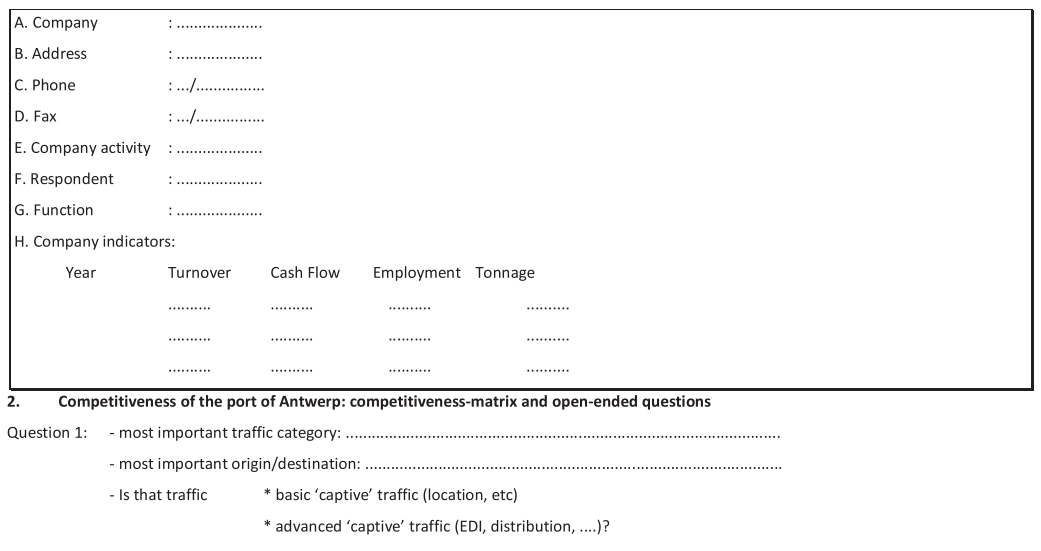

What is the port of reference for that traffic category?

Give a score from -2 to +2 on the elements in the Table. Compare the port of Antwerp to its 'port of reference' (benchmark) Possible scores:

$\begin{aligned}-2: & \text { very weak position of the port of Antwerp } \\ -1: & \text { weak } \\ 0: & \text { neutral (not weak, not strong) } \\ +1: & \text { strong } \\ +2: & \text { very strong } \\ 9: & \text { no opinion (missing value) }\end{aligned}$

Table: NEW COMPETITIVENESS MATRIX

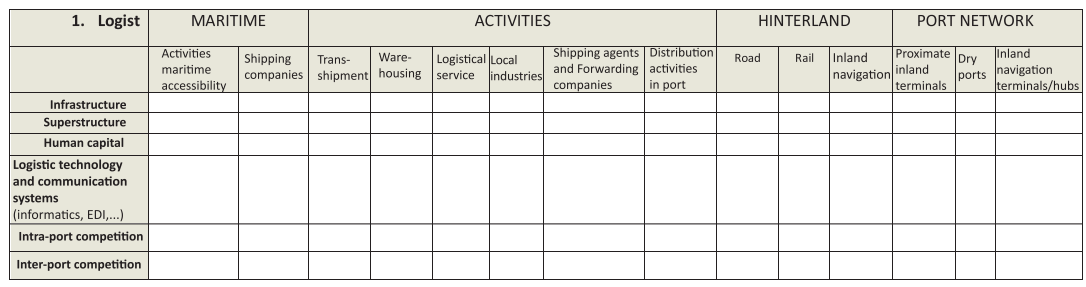




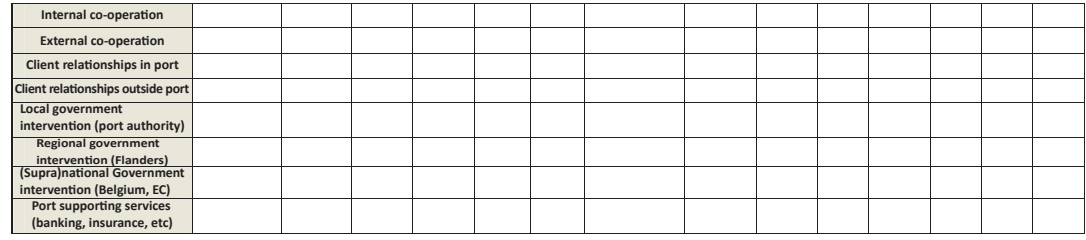

\begin{abstract}
Question 2: If you could give $a+3$, to which variable would you give it and why? If you could give $a-3$, to which variable would you give it and why?

Question 3: What impact will the weak scores have on the competitive position of the Antwerp seaport in the future, given an unchanged government policy?

Given your perceptions, which elements deserve priority in policy?

What needs to be done concretely?

Question 4: Which opportunities and threats do you think will be influencing severely the Antwerp seaport's competitiveness
\end{abstract} as regards containers?

Thank you for your kind co-operation

\title{
References
}

Acosta, M., Coronado, D., \& Mar Cerban, M. (2007). Port competitiveness in container traffic from an internal point of view: The experience of the Port of Algeciras Bay. Maritime Policy \& Management, 34(5), 501-520.

Anderson, C. M., Park, Y. A., Chang, Y. T., Yang, C. H., Lee, T. W., \& Luo, M. (2008). A game-theoretic analysis of competition among container port hubs: The case of Busan and Shanghai. Maritime Policy \& Management, 35(1), 5-26.

Barney, J. B. (1991). Firm resources and sustained competitive advantage. Journal of Management, 17(1), 99-120.

Bergqvist, R. (2012). Hinterland logistics and global supply chains. In D. W. Song \& P. Panayides (Eds.), Maritime logistics: A complete guide to effective shipping and port management. London: Kogan Page.

Brooks, M., Mccalla, R., Pallis, A., \& van der Lugt, L. (2009). Strategic cooperation in peripheral ports: The case of Atlantic Canada's ports. Canadian Journal of Transportation, 4(1), 29-42. 
Button, K. J. (1993). Transport economics (2nd ed.). Cheltenham: Edward Elgar.

Cahoon, S., Pateman, H., \& Chen, S. L. (2013). Regional port authorities: Leading players in innovation networks? Journal of Transport Geography, 27, 66-75.

Carbone, V., \& De Martino, M. (2003). The changing role of ports in supply-chain management: An empirical analysis. Maritime Policy \& Management, 30(4), 305-320.

Chiang, C. H., \& Hwang, C. C. (2009). Competitiveness of container ports in a region with cooperation and integration. Journal of the Society for Transportation and Traffic Studies, 1, 77-91.

Cheung, R., Tong, J., \& Slack, B. (2003). The transition from freight consolidation to logistics: The case of Hong Kong. Journal of Transport Geography, $11,245-253$.

Contractor, F., \& Lorange, P. (1988). Why should firms co-operate?-The strategy and economics basis for co-operative ventures. In F. Contractor \& P. Lorange (Eds.), Co-operative strategies in international business (pp. 3-30). New York: Lexington Books.

Cooper, M. C. (1994). Logistics in the decade of the 1990s. New York: The Free Press.

Cui, Q. (2017). Environmental efficiency measures for ports: An application of RAM-Tobit-RAM with undesirable outputs. Maritime Policy \& Management, 44(5), 551-564.

Cullinane, K., Bergqvist, R., \& Wilmsmeier, G. (2012). The dry port concept-Theory and practice. Maritime Economics \& Logistics, 14(1), 1-13.

De Langen, P. W. (2008). Ensuring hinterland access the role of port authorities. OECD/ITF, Joint Transport Research Centre, Discussion Paper, 18p.

De Martino, M., Errichiello, L., Marasco, A., \& Morvillo, A. (2013). Logistics innovation in seaports: An inter-organizational perspective. Research in Transportation Business \& Management, 8, 123-133.

Ducruet, C., \& Notteboom, T. (2012). Developing liner service networks in container shipping. In D. W. Song \& P. Panayides (Eds.), Maritime logistics: A complete guide to effective shipping and port management (pp. 77-100). London: Kogan Page.

Gordon, J. R., Lee, P. M., \& Lucas, H. C. (2005). A resource-based view of competitive advantage at the Port of Singapore. The Journal of Strategic Information Systems, 14(1), 69-86. 
Gulati, R. (1998). Alliances and networks. Strategic Management Journal, 19, 293-317.

Gulati, R., Nohria, N., \& Zaheer, A. (2000). Strategic networks. Strategic Management Journal, 21(Special Issue), 203-215.

Hagedoorn, J. (1993). Understanding the rationale of strategic technology partnering. Strategic Management Journal, 14, 371-385.

Hagedoorn, J. (1995). Strategic technology partnering during the 1980s: Trends, networks, and corporate patterns in non-core technologies. Research Policy, 24, 207-231.

Haezendonck, E., Pison, G., Rousseeuw, P., Struyf, A., \& Verbeke, A. (2000). The competitive advantage of seaports. International Journal of Maritime Economics, 2(2), 69-82.

Haezendonck, E., van den Broeck, J., \& Jans, T. (2011). Analysing the lobby-effect of port competitiveness' determinants: A stochastic frontier approach. Journal of Productivity Analysis, 36(2), 113-123.

Haralambides, H., \& Gujar, G. (2011). The Indian dry ports sector, pricing policies and opportunities for public-private partnerships. Research in Transportation Economics, 33(1), 51-58.

Hayut, Y. (1981). Containerization and the load center concept. Economic Geography, 57(2), 160-176.

Heaver, T., Meersman, H., \& Van De Voorde, E. (2001). Co-operation and competition in international container transport: Strategies for ports. Maritime Policy \& Management, 28(3), 293-305.

Hoshino, H. (2010). Competition and collaboration among container ports. The Asian Journal of Shipping and Logistics, 26(1), 31-47.

Jans, T. (2016). The impact of geographical clusters on environmental strategies (Ph.D. thesis defended in February 2016, Vrije Universiteit Brussel, Brussels).

Lavie, D. (2006). The competitive advantage of interconnected firms: An extension of the resource-based view. Academy of Management Review, 31(3), 638-658.

Marlow, P. B., \& Paixao, A. C. (2001). Agility, a key enabler in port competition. In International Association of Maritime Economists (Eds.), Annual Conference Proceeding (pp. 102-114). Hong Kong: Polytechnic University-Depterment of Shipping and Transport Logistics.

McEvily, B., \& Zaheer, A. (1999). Bridging ties: A source of firm heterogeneity in competitive capabilities. Strategic Management Journal, 20(12), 133-1156. 
Notteboom, T. E., \& Rodrigue, J. P. (2005). Port regionalization: Towards a new phase in port development. Maritime Policy \& Management, 32(3), 297-313.

Notteboom, T., \& Winkelmans, W. (2001). Structural changes in logistics: How do port authorities face the challenge? Maritime Policy \& Management, $28,71-89$.

Notteboom, T., \& Winkelmans, W. (2004). Overall market dynamics and their influence on the port sector (Factual Report-Work Package 1 FR-WP1). Brussels: European Sea Ports Organisation the Notion of Dry Ports. Maritime Economics \& Logistics, 14(1) (2012), 14-32.

Porter, M. E. (1990). The competitive advantage of nations. New York: Free Press.

Porter, M. E. (2000). Location, competition, and economic development: Local clusters in a global economy. Economic Development Quarterly, 14(1), $15-34$.

Robinson, R. (2002). Ports as elements in value-driven chain systems: The new paradigm. Maritime Policy \& Management, 29(3), 241-255.

Rodrigue, J.-P. (2010). Maritime transportation: Drivers for the shipping and port industries. In International Transport Forum: ITF (2010), Highlights of the international transport forum 2010: Transport and innovation: Unleashing the potential. Paris: OECD Publishing. http://dx.doi.org/10.1787/ itf_highlights-2010-en.

Rodrigue, J.-P., \& Notteboom, T. (2009). The terminalization of supply chains: Reassessing the role of terminals in port/hinterland logistical relationships. Maritime Policy \& Management, 36(2), 165-183.

Rodrigue, J.-P., Comtois, C., \& Slack, B. (2009). The geography of transport systems. Routledge: Hofstra University, Department of Global Studies \& Geography.

Roso, V., Woxenius, J., \& Lumsden, K. (2009). The dry port concept: Connecting container seaports with the hinterland. Journal of Transport Geography, 17(5), 338-345.

Slack, B. (1985). Containerization, inter port competition and port selection. Maritime Policy \& Management, 5(12), 293-303.

Song, D.-W. (2003). Port co-opetition in concept and in practice. Maritime Policy \& Management, 30(1), 29-44.

Song, D.-W., \& Panayides, P. M. (2008). Global supply chain and port/terminal: Integration and competitiveness. Maritime Policy \& Management, 35(1), 73-87. 
Suárez-Alemán, A., Serebrisky, T., \& Ponce De León, O. (2017). Port competition in Latin America and the Caribbean: The role of concessions and competition policy. Maritime Policy \& Management, 45(5), 1-19.

Teece, D. J., Pisano, G., \& Shuen, A. (1997). Dynamic capabilities and strategic management. Strategic Management Journal, 18(7), 509-533.

Teng, J. Y., Huang, W. C., \& Huang, M. J. (2004). Multicriteria evaluation for port competitiveness of eight East Asian container ports. Journal of Marine Science and Technology, 12(4), 256-264.

UNCTAD (United Nations Conference on Trade and Development). (1982). Multimodal transport and trade facilitation. Geneva: UNCTAD.

Van den Berg, R., \& De Langen, P. W. (2011). Hinterland strategies of port authorities: A case study of the Port of Barcelona. Research in Transportation Economics, 33, 6-14.

Van Der Horst, M. R., \& De Langen, P. W. (2008). Coordination in hinterland transport chains: A major challenge for the seaport community. Maritime Economics \& Logistics, 10(1-2), 108-129.

van der Horst, M. R., \& van der Lugt, L. M. (2011). Coordination mechanisms in improving hinterland accessibility: Empirical analysis in the port of Rotterdam. Maritime Policy \& Management, 38(4), 415-435.

Veenstra, A., Zuidwijk, R., \& van Asperen, E. (2012). The extended gate concept for container terminals: Expanding the notion of dry ports. Maritime Economics \& Logisticsn, 14(1), 14-32.

Verhoeven, P. (2009). European ports policy: Meeting contemporary governance challenges. Maritime Policy \& Management, 36(1), 79-101.

Wan, Y., Zhang, A., \& Li, K. X. (2018). Port competition with accessibility and congestion: A theoretical framework and literature review on empirical studies. Maritime Policy \& Management, 45(2), 239-259.

Wang, J. J., \& Slack, B. (2004). Regional governance of port development in China: A case study of Shanghai International Shipping Center. Maritime Policy \& Management, 31(4), 357-373.

Wassmer, U., \& Dussauge, P. (2011). Value creation in alliance portfolios: The benefits and costs of network resource interdependencies. European Management Review, 8(1), 47-64.

Wernerfelt, B. (1984). A resource-based view of the firm. Strategic Management Journal, 52, 171-180.

Wilmsmeier, G., Monios, J., \& Lambert, B. (2011). The directional development of intermodal freight corridors in relation to inland terminals. Journal of Transport Geography, 19, 1379-1386. 
World Bank. (2007). The evolution of ports in a competitive world in 2007. Washington, DC: The World Bank.

Xing, W., Liu, Q., \& Chen, G. (2018). Pricing strategies for port competition and cooperation. Maritime Policy \& Management, 45(2), 260-277.

Yap, W. Y., \& Lam, J. S. (2004). An interpretation of inter-container port relationships from the demand perspective. Maritime Policy \& Management, 31(4), 337-355.

Open Access This chapter is licensed under the terms of the Creative Commons Attribution 4.0 International License (http://creativecommons. org/licenses/by/4.0/), which permits use, sharing, adaptation, distribution and reproduction in any medium or format, as long as you give appropriate credit to the original author(s) and the source, provide a link to the Creative Commons license and indicate if changes were made.

The images or other third party material in this chapter are included in the chapter's Creative Commons license, unless indicated otherwise in a credit line to the material. If material is not included in the chapter's Creative Commons license and your intended use is not permitted by statutory regulation or exceeds the permitted use, you will need to obtain permission directly from the copyright holder.

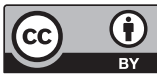

